ARTICLE

DOI: $10.1057 /$ s41599-017-0030-3

\title{
The Gothic bet: Riccardo Freda's I vampiri (1957) and the birth of Italian horror cinema from an industrial perspective
}

\author{
Michael Guarneri ${ }^{1}$
}

\begin{abstract}
Scholars tend to agree on Riccardo Freda's I vampiri (1957) being the first Italian horror film. Indeed, prior to Freda's Paris-set Gothic potboiler, which mixes the Erzsébet Báthory legend with the Frankenstein myth, no horror movie proper seems to have been made in Italy. Drawing from a series of interviews given by the director over the years, the existing literature about Italian horror cinema conceives of I vampiri as a film appearing out of the blue, born on the fly because of an alleged bet and shot at breakneck speed in a couple of weeks. Freda's use of the word "bet" in these interviews, and the film's meagre returns at the domestic box-office, have led academics to see I vampiri as an epically brave, if commercially unsuccessful, challenge to the dominant taste-an experiment carried out by inventive yet unlucky pioneers, skilled artisans too ahead of their time. Resultantly, a great deal has been written about "the supposedly non-industrial quality" of Italian horror movies, "which apparently relied only on the craftsmanship of talented directors" (Di Chiara, 2016, p 30), such as Freda, Mario Bava and Antonio Margheriti. By revisiting Freda's often-quoted anecdotes about the extemporaneous genesis of I vampiri in the light of the film's production and distribution data preserved at the Archivio Centrale dello Stato in Rome, the present article seeks to shift the focus of discussion from the 'Great Men' to the broader economic, political and cultural context in which I vampiri was manufactured. The article reveals that it was the very nature of the post-war Italian film industry as regulated by the ChristianDemocrat laws of 1949 that allowed Freda and his producers Ermanno Donati, Luigi Carpentieri and Goffredo Lombardo to place their bet on an unprecedented 'Gothic made in Italy'. By adopting this materialistic approach, Freda's experiment in terror ultimately emerges as a minor, low-risk speculation, and a market test confirming a long-standing Italian bias against home-grown horror narratives, to the point that it is more appropriate to consider Terence Fisher's Dracula (1958) as the 'originary film' of Italian horror cinema.
\end{abstract}

\footnotetext{
${ }^{1}$ Northumbria University, Newcastle upon Tyne, UK. Correspondence and requests for materials should be addressed to M.G. (email: michael.guarneri@northumbria.ac.uk)
} 


\section{Introduction}

iven Italy's almost non-existent horror narrative tradition prior to the late 1950s, and drawing from a series of interviews granted by director Riccardo Freda over the years (Lourcelles and Mizrahi, 1963; Cozzi, 1971; Colombo and Tentori, 1990; Della Casa, 1993; Pisoni and Ferrarese, 2007), film historians essentially see first Italian horror movie I vampiri (1957) as a random experiment written and shot on the fly, for reasons that have more to do with its director's idiosyncrasies and taste for challenge than anything else. Resultantly, many academics have been stressing "the supposedly non-industrial quality" of the 1957 prototype and all the following Italian horrors made from late 1959 onwards, "which apparently relied only on the craftsmanship of talented directors" (Di Chiara, 2016, p 30) like Freda, Mario Bava, Antonio Margheriti and so on. With the aim to enrich these largely anecdotal accounts of founding fathers' 'Great Deeds', the present article positions filmic text $I$ vampiri into its too-often-neglected industrial context. If 'Great Man' historiography is perhaps inevitable when discussing national cinemas and 'first' films, it certainly is possible to tame its rhetorical excesses by demonstrating that-as a cornerstone of commercial cinema-genre movies don't just pop up out of the blue due to the sheer volition of creative individuals, but are manufactured within and shaped by an institutional and regulatory framework in which local and international factors intertwine. By adopting this materialistic approach, Freda's experiment in terror ultimately emerges as a minor, low-risk speculation, and a market test confirming a long-standing Italian bias against home-grown horror narratives, to the point that it is more appropriate to consider Terence Fisher's Dracula (1958) as the 'originary film' of Italian horror cinema.

\section{The prehistory of Italian horror}

Transposing the Erzsébet Báthory legend and the Frankenstein myth to 1950s Paris, ever since its April 5th 1957 national premiere I vampiri has been considered by Italian critics as "the first 'black film' [film nero]" (Anonymous, 1957c), "the first [...] Edgar-Allan-Poe-style film di orrore" of Italian cinema (Marinucci, 1957). While there have been attempts to trace a 'horror sensibility' in pre-1957 Italian movies adapting the very few ventures of Italian writers into the fantastic, ${ }^{1}$ reworking texts from British, German and American literature, ${ }^{2}$ or simply displaying macabre imagery and supernatural elements ${ }^{3}$ (Venturini, 2014; Hunter, 2016), film scholars tend to agree with 1957 critics on I vampiri being the first, full-fledged Italian horror (Mora, 1978; Newman, 1986; Troiano, 1989; Pezzotta, 1997; Di Chiara, 2009; Della Casa and Giusti, 2014; Curti, 2015). ${ }^{4}$ Given that the notion of 'horror' as a film genre was formalised by the AngloAmerican press and censorship bodies in the early 1930s, after the inception of Universal's and Paramount's horror cycles (Peirse, 2013), the twenty-year gap between the official codification of the cinematic genre and its first manifestation in Italy strikes as surprising, all the more because Italian folklore abounds with ghosts and witches (Agazzi, 1979) and Italy has been a favourite setting for English and American Gothic novels and uncanny short stories since the 18 th century. ${ }^{5}$ This conspicuous absence has been variously explained.

The main reason put forward by film scholars is a cultural one: post-Enlightenment Italy failed to foster a tradition of horrorthemed literary fiction comparable to British and German ones, ${ }^{6}$ and without a heritage of literary horrors no national horror cinema could flourish in the first half of the 20th century. According to Curti (2011), such failure was due to the fact that, from the early 19th century until well into the 20th, prominent intellectuals like Giacomo Leopardi, Alessandro Manzoni and
Benedetto Croce championed rationalism, classicism and realist literary genres as the true expressions of the 'Italian character', repeatedly bashing and ridiculing Anglo-American Gothic fiction and English and German Romanticism for their focus on the disproportionate, the undefined, the macabre, the oneiric and the supernatural. $^{7}$ A cursory look at vampire-themed narratives in Italian literature provides perfect examples of the unpopularity of the home-grown fantastic in the bel paese. For instance, Franco Mistrali's Il vampiro. Storia vera-arguably the first Italian vampire novel-came into being only in 1869, i.e., decades after John W. Polidori's 1819 trailblazing short story The Vampyre and its very many English and French stage adaptations achieved huge success all over Western Europe. Moreover, the title chosen by Mistrali ('The vampire. A true story') manifests the unease of the Italian writer in approaching the critically discredited genre of the fantastic, and so does the plot. Set in 1862 in Monte Carlo, just outside Italian borders, the story adopts the firstperson perspective of a detective-character and revolves around Polish-Russian-French count Alfredo Kostia. A moody thirtyyear-old man, the aristocrat loves to read Romantic poetry and ends up falling in love with Metella, a mysterious woman who looks exactly like his former lover, the departed countess Pia Ludowiskoi. Upon Kostia's opening Pia's grave and finding it empty, the story takes a supernatural twist: Metella is believed to be a vampire, a "blood-drinking, sepulchral spectre [that] leaves the cemetery at night, wrapped in its shroud, looking for sleeping victims", "young people" to put under the curse of "its fatal love" (Mistrali, 1869, p 42). Yet, the supernatural soon gives way to the rational. The narrator teams up with the Monte Carlo police and discovers that Pia faked her death and took on the 'revenant' identity of Metella to drive Kostia mad: she is but a pawn in the hands of the Secret Society of Vampires, a group of anti-Zarist conspirators who dabble in blood transfusions and kill their political opponents with golden needles chiselled with cabalistic symbols. After Mistrali's novel, which was neither a bestseller nor a critical success, vampire figures would play a leading role in Italian literature only in about a dozen short stories prior to the late 1950s. ${ }^{8}$ The exception that proves the rule is Mary Tibaldi Chiesa's Gli enigmi del vampiro ('The riddles of the vampire'), a book-length Italian translation/ reworking of an 11th-century collection of Indian novellas narrated by a vetala, the Hindu equivalent of a vampire. Printed by Milanese publishing house Mondadori in 1936, Gli enigmi del vampiro boasts a preface by Orientalist scholar Angelo Maria Pizzagalli confirming the Italian 'rationalist prejudice' against the fantastic:

We [Italians] don't believe in vampires and sprites anymore; nowadays these are but fantasies good for children and old ladies [...]; our philosophy taught us that unsolvable riddles are just wrongly-posed questions, whose words are devoid of any meaning and connection to concrete reality. [...] We don't believe in mysterious practices, in black magic rituals; we don't believe that man is allowed to obtain superhuman powers through murder. Rather, we believe in the miraculous power of imagination and love, which makes men stronger and pushes them to achieve what seems impossible. However, if we don't believe in magic transformations, we are perhaps more fascinated by them than the people of India themselves, because in the esoteric we find a sense of novelty, a touch of exoticism that strikes a chord that, unfortunately, Italian writers have touched so rarely: the chord of fantastic creations (Tibaldi Chiesa, 1936, p 15-19). 
The same argument, based on the authority of Leopardi, Manzoni and Croce, returns over and over in Italian film criticism too, every time an Italian director would try to unsettle the audience by pushing the boundaries of verisimilitude. For example, a 1913 review of Il suicida n. 359 (1913)-a free adaptation of Robert Louis Stevenson's 1878 short story collection The Suicide Club-reads: "I think that Italian companies should not make this kind of frightening, non-plausible films. Certain acts of collective madness might often happen in the Nordic mists of the Thames, but certainly not on the lovely, sunny shores of river Po" (quoted in Bernardini and Martinelli, 1993, p 271). Reviewing La terrificante visione (1915), another critic noted that Italian fantastic films lack "the talent in the strange, the genius in the unlikely, the vivacity and courage in the illogic" to be found in their foreign homologues that had launched the 'fantastic trend' in the first place (quoted in Martinelli, 1992, p 243). This long-standing bias is perfectly encapsulated by journalist Pietro Bianchi in a 1940 review of Bride of Frankenstein (1935): "We good Mediterraneans have no sympathy for horrors. We leave spirits, monsters and ghosts to Nordic people" (quoted in Venturini, 2014, p 5). More than a decade after Bianchi's categorical refusal, the horror genre was still perceived as completely alien to Italian culture, to the point that the first Italian-language article surveying the history of cinematic horrors was written by a Spanish scholar tracing the fathers of the "terrorific" or "truculent" film (the expression 'horror cinema' is never employed throughout the text) in France, Scandinavia, Germany and the United States (Rotellar, 1952). Consequently, upon writing I vampiri in late 1956, Freda opted for setting his Frankensteinian-vampiric tale abroad, Mistrali-style, while his producers decided mid-shoot to remove the most fantastic and gruesome scenes and insert a police-investigation subplot which was deemed to be more appealing to Italian audiences than pure horror, given the huge commercial success of Anglo-American whodunit and crime novels published in Italian translation ever since 1929 in Mondadori's I libri gialli series. ${ }^{9}$ Furthermore, as recounted by Freda, by the late 1950s the prejudice against fantastic films 'made in Italy' was something of a donné even among Italian audiences, which led the director to adopt the Anglophone pseudonym Robert Hampton for his later sci-fi/horror hybrid Caltiki il mostro immortale (1959), an ultralow-budget imitation of The Quatermass Xperiment (1955), X the Unknown (1956) and The Blob (1958):

I had the idea [of crediting myself as Robert Hampton] while I was in the foyer of a cinema in Italy. I noticed that, after glancing at the film poster for I vampiri, a lot of people said: "Riccardo Freda? Gianna Maria Canale? It's an Italian film, so it must not be very good. If it came from the US, it would be worth seeing!" (quoted in Lourcelles and Mizrahi, 1963, p 28).

As a matter of fact, Italy had been a strong importation market for Hollywood fantastic cinema ever since the silent era. Although occasionally beset by censorship problems, pictures such as Dr. Jekyll and Mr. Hyde (1920), The Phantom of the Opera (1925), Frankenstein (1931) and its sequels, Dr. Jekyll and Mr. Hyde (1931), The Mummy (1932), The Invisible Man (1933), Mystery of the Wax Museum (1933), Dr. Jekyll and Mr. Hyde (1941), The Phantom of the Opera (1943), The Thing from Another World (1951) and House of Wax (1953) circulated widely in Italy between the mid-1920s and the late-1950s (Quaglietti, 1991; Venturini, 2014). For unknown reasons, though, Hollywood's vampire exploits like Dracula (1931), Mark of the Vampire (1935), Dracula's Daughter (1936) and Son of Dracula (1943) seem to have never been imported, just like Nosferatu, eine
Symphonie des Grauens (1922) and Vampyr, ou l'étrange aventure de David Gray (1932): prior to 1957, the only vampire-themed movies screened in Italy were tongue-in-cheek 'monster mashups' House of Dracula (1945) and Abbott \& Costello Meet Frankenstein (1948), and detective stories London after Midnight (1927) and The Return of Doctor X (1939) - the latter sharing more than one similarity with I vampiri's original screenplay credited to Freda, Piero Regnoli and the inexistent Rijk Sijöstrom (a 'scientific vampire' that feeds via blood transfusions, the reanimated corpse of a child murderer, an inquisitive journalist determined to solve a string of homicides...). ${ }^{10}$

Besides the rationalist mindset of the Italian intelligentsia, the scant heritage of cinematic horrors before I vampiri is generally explained through three 'structural causes' relating to the Italian powers that be. Firstly, in response to moralising campaigns launched by magistrates and high-ranking clergymen, a state-run Italian Censorship Office was created in 1913 by the Centrist government, in order to ban from Italian screens "truce, repugnant or cruel scenes, including scenes of violence against animals; shocking murders and suicides and, in general, perverse actions or events that might perturb the spirits, teach or spur people to commit crimes and do evil" (Royal Legislative Decree 532 of May 31st 1914, quoted in Argentieri, 1974, p 20-21). Secondly, we have both the moralising influence of the Vatican on said state-run board of film censors within the frame of the alliance between the Holy See and powerful Italian politic parties of Roman-Catholic ideology (Treveri Gennari, 2011; Barattoni, 2013), and the diligent, incessant activity of Vatican's own censors to "influence film producers by controlling the market of Catholic cinemas, which [...] were open only to films possessing moral standards established by the Vatican" (Valli, 1999, pp 8). In fact, starting with its foundation in March 1935, the Vatican film censorship office Centro Cattolico Cinematografico took upon itself the task of assessing the morality of all Italian and foreign films to be released in Italy, and published its 'judgements' on widely-read bulletins, newspapers and magazines to make sure that 'immoral' movies would not be exhibited in the very many Italian theatres owned by the Catholic Church itself (the socalled parish cinemas) or owned/run by devout Catholics. Thirdly, during both the Fascist ventennio and the ChristianDemocrat 'absolute rule' of the post-war years, the ruling rightwing parties closely monitored the content of the films ever since the screenwriting phase via a special governmental bureau, pressuring industry people to focus on light entertainment, while most left-wing intellectuals tended to despise genre cinema of all kinds, and to devalue fantastic cinema in particular as an escapist flight from the analysis of present-day social reality. All this resulted in an almost total absence of Italian horror cinema proper until 1957 or, at best, in the production of a few films using Gothic and horror paraphernalia for laughs: Preferisco l'Inferno (1916), Maciste all'Inferno (1925) and Totò all'Inferno (1955) mix Dante Alighieri's and Gustave Doré's visions of Hell with revue-like comedy sketches and slapstick; L'allegro fantasma (1941), C’è un fantasma nel castello (1942) and Abracadabra (1952) explain away supernatural events as the shenanigans of clumsy crooks masquerading as ghosts; Incanto di mezzanotte (1940), Quel fantasma di mio marito (1950) and La paura fa 90 (1951) turn the 'vengeful ghost' scenario on its head by featuring good-hearted or inept spectres in a romantic-comedy plot.

\section{The birth of Italian horror cinema}

With regard to the extemporaneous genesis of I vampiri, in 1971 Freda stated that he started making horror movies 
because of a bet. I was talking with two producers one day, [Ermanno] Donati and [Luigi] Carpentieri. I said that a film could be made in 2 weeks, and they replied that it was impossible. I insisted, so they phoned [Goffredo] Lombardo, [owner of production and distribution company Titanus]: they explained to Lombardo my proposal and asked if he wanted to distribute the film once it was finished. He accepted without much enthusiasm and I very quickly wrote a screenplay for I vampiri, which was shot in 12 days. Then I quit the job because I had an argument with the producers, and they completed the rest of the picture in 2 days. The movie was set in Paris but, thanks to the miniatures and tricks I created with cinematographer Mario Bava, we shot it in the courtyard of Titanus studio, in Rome (quoted in Cozzi, 1971, p 27-28). ${ }^{11}$

In the early 1990s, Freda repeated the anecdote almost word by word, insisting on the low-budget nature of the project:

I have always liked to be the first in filmmaking. I vampiri was born in quite curious a way. I was in Donati and Carpentieri's office, we were thinking about some stories to bring to the screen, and I somewhat casually proposed to make a horror film. They asked me if I had some ideas ready to pitch. I didn't, but I told them that I could come up with something in $24 \mathrm{~h}$. So I brought them a story on the next day. I didn't write anything, I just recorded my voice on tape. I also made all the sound effects myself, the creaking doors and so on. It was very funny. Donati and Carpentieri phoned Lombardo, who accepted my pitch right away. I guess it was one of Lombardo's 'good days', and the fact that I didn't ask much for my film helped: I agreed to shoot the movie in about 10 days, demanding only Gianna Maria Canale as lead actress, Mario Bava as cinematographer and Beni Montresor as production designer (quoted in Della Casa, 1993, p 60).

What Freda perfected through countless interviews between the early 1960s and the late 1990s is the typical retrospective tale about post-war Italian genre cinema, in which skilled artisans do battle with the lack of money and time to break new ground for the generations of filmmakers to come (Faldini and Fofi, 1979; Faldini and Fofi, 1981). And of course, as in the American Western epics Freda had loved ever since his childhood (Freda et al., 1981), there is no happy ending to reward the heroic pioneers: "There was no audience for horror films at that time in Italy. We hired a couple of ladies to scream their lungs out during a premiere screening of I vampiri, but it was a half-fiasco and we laughed about it a lot..." (Freda, quoted in Pisoni and Ferrarese, 2007, p 43).

Official figures confirm Freda's version. According to the documents submitted by Donati and Carpentieri to the government-run Italian State Cinema Bureau, the production of $I$ vampiri started in November 1956 with a 20-day shooting schedule. The final budget was 142 million lira-120 million for the shooting and 22 million for post-production and publicity. ${ }^{12}$ Donati and Carpentieri's company Athena Cinematografica and Lombardo's Titanus invested a mere 16 million each. Additional money came from a 50-million state loan, on which the producers asked an extra 25. During its 1957-1964 exhibition tour around Italy-the second biggest market in the world for number of tickets sold and active movie theatres throughout most of the 1950s and 1960s (Quaglietti, 1980) - I vampiri collected only $125,261,726$ lira (Rondolino and Levi, 1967, p 128), while the topgrossing Italian movies first released in 1957 were totalling between 700 and 800 million over the same period. ${ }^{13}$ As for foreign distribution, between 1957 and the mid-1960s I vampiri circulated under various titles and in different cuts in France, West Germany and the United States, but neither foreign box-office receipts nor documents relating to international distribution deals are currently in the public domain. ${ }^{14}$ Thus, as it can be inferred from the 'extemporaneous bet' anecdote, Freda basically involved Donati, Carpentieri and Lombardo in a market test: they gambled on something new-an Italian film di orrore-and, as far as we know, the experiment didn't turn out a smash-hit anywhere. Quite ironically, much more successful in Italy was the Italian edition of Richard Matheson's 1954 sci-fi novel I Am Legend, first published under the Fredian title I vampiri in October 1957 by prestigious Milanese publishing house Longanesi. ${ }^{15}$ If the first 'horror made in Italy' was a lost bet, though, Athena Cinematografica and Titanus weren't gambling big money, as I vampiri had all the key-characteristics of a low-budget project: a tight shooting schedule (dramatically sped up by the Italian common practice of post-shoot dubbing), a crew of technicians expert at cutting costs, no expensive actors (top-billing Gianna Maria Canale, a fairly-popular sex symbol of Italian adventure cinema since 1948, was paid less than 8 million lira, more or less the same salary as the director). But in order to understand why Donati, Carpentieri and Lombardo poured 32 million cash into a Gothic potboiler whose only box-office appeal was the presence of Canale, and why they ended up laughing about its mediocre revenues, it is necessary to describe the birth of the post-war Italian film industry as a state-subsidised, distribution-driven, rampantly speculative business.

Preoccupied with declining audience figures in the US film market, since the end of World War Two Hollywood studios had started dumping hundreds of films from their 1937-1945 backlist catalogues on the newly-deregulated Italian market, ${ }^{16}$ with the effect of precluding Italian films from any chance of wide domestic release. The chain-reaction on almost all sectors of the Italian film industry was dramatic: very few screenings of Italian films, meagre box-office receipts and no profit-making for Italian producers, no capital to invest in filmmaking, a resultant crisis and vast unemployment in one of Italy's most lucrative economic activities (Wagstaff, 1998). The very same thing was happening in post-war France, to the point that in 1946 Italy and France started signing a series of bilateral agreements aiming to "oppose American prevarication" (Freda, quoted in AAVV, 1995, p 98) by pooling the two countries' technical/artistic/financial resources and creating a single transnational film-market out of two separate national ones (Burucoa, 1995). Hollywood studios were not impressed by Italo-French co-production agreements, or by similar business partnerships subsequently signed between Italy and West Germany, Austria and Spain: American companies simply kept flooding the European market with their movies, effectively maintaining a hegemonic position. This situation was harshly denounced in a 1948 manifesto written by Italian film workers and critics. Besides accusing the Italian government of turning a blind eye to Hollywood's aggressive dumping policies and massive export of lira to the US, film workers blamed the crisis on the inexistent bank credit for Italian film production (Quaglietti, 1980). In 1949, after the unrest of the various components of the Italian film industry had reached a boiling point, Christian Democrat Undersecretary to the Presidency of the Council of Ministers Giulio Andreotti was able to pass two laws aiming at breaking the Hollywood monopoly and boosting Italian film production while "acquiring the maximum consensus among conflicting categories (exhibitors, distributors, producers, facility workers) in order to gain political control over Italian film production" (Baschiera and Di Chiara, 2010, p 31): law 448 of July 26th 1949, also known as 'leggina', and law 958 of December 29th 1949, also known as 'legge Andreotti'. 
Relying heavily on Fascist-era legislation (Corsi, 2001), the system put in place in 1949 by Andreotti made "the Italian State [...] the biggest cinematograph in Italy" (Andreotti's 1950 public speech, quoted in Quaglietti, 1980, p 78). Firstly, the two laws created a state-managed 'special fund for cinematography', fed by a ten-year-fixed 2.5-million-lira 'deposit' to be paid on each foreign film over 1000 metres that distribution companies wished to import and dub into Italian. Catching two birds with one stone, Andreotti managed to impose a restriction on Hollywood monopoly ${ }^{17}$ and find the resources to provide the bank credit that Italian film workers were asking for. Secondly,

a special state commission was created [as part of the Italian State Cinema Bureau] in order to ascertain the nationality of the films shot on Italian territory. If a given film, in spite of foreign investments and the presence of foreign actors and technicians, was certified to be 'of Italian nationality', it could obtain two benefits: 1) the 'mandatory scheduling', as part of a 'national quota' mechanism according to which Italian films had to be screened in Italian theatres for at least 80 days per year; 2) state incentives to production under the form of tax refunds ( $10 \%$ of the Italian box-office gross, plus an extra $8 \%$ for films that the state commission deemed artistically valid)

(Di Chiara, 2009, p 23).

This system "remained virtually unmodified until 1965" (Baschiera and Di Chiara, 2010, p 31): law 897 of July 31st 1956 simply unified the 1949 laws into a single text, substituting the guaranteed-10\%-plus-eventual- $8 \%$ tax refund with an automatic $16 \%$ tax refund, and increasing both the 'dubbing deposit' (from 2.5 to 5.5 million) and the 'national quota' (from 80 to 100 days $)^{18}$

We can now begin to understand why Donati and Carpentieri, the owners of a tiny production company, were so easily convinced by Freda to back up an unprecedented experiment in terror such as I vampiri. Not only the film was a low-budget effort but, according to the law, up to $60 \%$ of its budget could be covered by the State with money from the 'dubbing deposit' of the over 200 foreign films imported every year in Italy from January 1st 1950 onwards. For the loan to be granted, however, the State required a garanzia (an assurance to recoup at least part of the investment), and it is here that the role of Titanus becomes important. As stressed by Freda (quoted in Cozzi, 1971, p 27), Athena Cinematografica did not contact Titanus' head as a producer: "[Donati and Carpentieri] phoned Lombardo [...] and asked if he wanted to distribute the film once it was finished". In other words, Donati and Carpentieri wanted first and foremost to secure their upcoming film a place on the domestic market via Titanus, one of Italy's oldest and most prestigious distribution companies. The equation is simple: striking a distribution deal before production even starts means having a fair chance to recoup the production costs via box-office gross and pay back the state loan necessary to make the movie. What Athena Cinematografica was looking for, though, was not an affidavit. More concretely, Donati and Carpentieri wanted an advanced payment from the future distributor of their film, under the form of minimo garantito, i.e., a certain sum based on a rough, 'minimum estimate' of the net box-office receipts the movie would collect over the course of its two-or-three-year tour around Italy's theatres. And they got it, as testified by the expression "Titanus, minimo garantito" appearing in a financial plan submitted by Athena Cinematografica to the Italian State Cinema Bureau: since Titanus was active in both production and distribution, Lombardo almost certainly reckoned that financing a 'certifiedItalian' feature would give him the possibility to avoid paying the 'dubbing deposit' on a foreign film he wished to import in the future, as the 'leggina' allowed for this dispensation and even legalised the 'dubbing fee-waiver' trade among film companies (Quaglietti, 1980; Corsi, 2001). Official documents report a 16-million cash investment by Lombardo followed by the concession of a 50-million state loan, which confirms what scholars have so far written about Italian genre cinema as a distributiondriven business in which "producers could obtain money in advance from distributors in exchange for domestic or foreign distribution rights; using these distribution rights as garanzia, producers could easily gain access to state credit" (Di Chiara, 2009, p 25). ${ }^{19}$

Finding a distributor willing to grant the minimo garantito and thereby asking for a state loan was only half of the producers' job. The other half consisted in demonstrating to the state commission created by the 'legge Andreotti' that the film was 'of Italian nationality', to obtain the 'mandatory scheduling' and 'tax refunds' benefits. The procedure to get an 'Italian nationality' certificate was more or less the same as the one to ask for a state loan. To access state credit, Donati and Carpentieri had already submitted to the Italian State Cinema Bureau the following, mandatory documents: the screenplay of I vampiri (in order for government officials to enact censura preventiva, a 'preventive censorship ${ }^{20}$ discouraging the making of movies that may clash against Christian Democrats' ideology); the estimated budget; financial plans to cover said budget; the shooting schedule; a complete list of cast and crew with personal data and contracts thereof (a certain number of Italian workers had to be employed for the film to qualify as Italian); contracts for the rental of Italian film studios, dubbing facilities and film labs (a minimum number of days was required); contracts relating to possible foreign coproductions and domestic/international distribution agreements. After the film was greenlit (read: financed by the State), shot, edited, dubbed and had obtained from the government-run Italian Censorship Office the permission to be publicly screened (visto di censura), the final step for Donati and Carpentieri to take was merely bureaucratic, namely submitting to the Italian State Cinema Bureau the cost statement for I vampiri, the visto di censura and proof of first public screening in Italy via the designed distributor.

So upon I vampiri's premiere on April 5th 1957 (Anonymous, 1957a), Athena Cinematografica obtained the 'nationality certificate' for the first Italian horror movie, and accessed the 'mandatory scheduling' and ' $16 \%$ tax rebates' benefits. This is not surprising. Aiming at making the various categories of the industry prosper only at the condition of focusing on light escapism and avoiding explicit sexual content and political issues that would have hurt the Catholic principles and centre-right agenda of the ruling party, the highly-centralised 'Andreotti system', with its multiple layers of censorship, targeted supposedly 'politically reactionary' works by alleged 'Communistsympathisers' such as Pietro Germi and Vittorio De Sica (Argentieri, 1974; Quaglietti, 1980; Barattoni, 2013), while leaving genre cinema of all kinds a relative freedom, especially when movies were set in remote historical epochs and/or in foreign countries. Consequently, although much ridiculed at the censura preventiva stage for its adoption of the tritest clichés from "certain crude, unrefined 19th-century British and French popular literature", I vampiri's screenplay was approved by state officials and the finished film was passed uncut by the Italian Censorship Office as VM16 (forbidden to people under the age of 16), ${ }^{21}$ thus confirming that, after 1949,

for an adventurous though inexperienced producer it became very easy to make [genre] movies [in Italy], also because Italian cinema could count on many well-trained professionals skilled at containing costs. Once a picture had 
been sold in advance to a distributor, it was relatively easy for its producer to access the governmental loan fund. Then, as a rule, the producer actually made the movie using about half of the original estimated budget, keeping the rest as his wages; the distributor was left to face the uncertainties of the market (Baschiera and Di Chiara, 2010, p 31).

In view of this state-patronised 'anti-risk cushion' and the producers' tendency to "generate profits not by investing money, but by subtracting it from the film's budget" (Bizzarri, 1957, p 1380), Freda's 'bet' anecdote and its 'we all laughed so hard about it' coda can finally be put into the right perspective and I vampiri defined as a minor, low-risk speculation rather than an epically brave, if unsuccessful, challenge to dominant taste launched by a 'wild bunch' of pioneers. In Italy both small producers like Athena Cinematografica and big companies like Titanus would be encouraged to invest in film production for purely financial reasons, as "tax refunds on box-office receipts always assure a minimum margin of profit, even if the film barely manages to cover its production expenses" (Corsi, 2001, p 53). Indeed, an issue of cultural magazine $I l$ ponte contemporary to the Italian premiere of Freda's film featured a polemic essay titled Cinema senza industria ('Cinema without an industry'), heavily criticising the 1949 laws for handing Italian film production over to companies owning nothing but their names, speculators who make films without risking anything from their own pockets:

In the 1954-1955 season, the impressive number of 200 Italian film production companies was recorded: a real 'pulverisation' of the productive sector. Basically, [...] a production company was born for each new film to be made. Between 1953 and 1954, everybody wanted to 'play the game', and perhaps they managed to produce one movie, but then they stopped: these initiatives lacked financial, industrial and commercial solidity. In the 1954-1955 and 1955-1956 seasons, 100 companies produced only one film (not one film in each season, but one film during the two seasons) (Bizzarri, 1957, p 1377-1379).

In case of financial problems (for instance due to the utter commercial failure of a movie), these speculators would simply go bankrupt to avoid paying creditors and immediately try to go back in business under a different name, which is what Donati and Carpentieri apparently did in the late 1950s, when Athena Cinematografica, active since the early 1950s and with a dozen genre films under its belt, suddenly became Panda Cinematografica.

November-December 1956 saw the shooting of I vampiri and Hammer's The Curse of Frankenstein (1957), with the Italian release of the former predating by a month the British release of the latter. Meanwhile, in the US, pre-1948 'Universal horror' classics began to be broadcast on syndicated TV by Columbia in a highly-successful package known as Shock Theater (Clarens, 1968). October-November 1957 saw both the Mexican release of El vampiro (1957), produced by Mexican actor Abel Salazar to exploit the domestic success of Frankensteinian rip-off Ladrón de cadáveres (1956), and the shooting of Hammer's Dracula. For these reasons, 1956 and 1957 are seen as the landmark years of a "Gothic revival" that took place on the two shores of the Atlantic and involved Italian and Mexican film production companies, Hammer and its American 'silent partners' Associate Artists Productions, Warner Bros. and Universal, soon joined by American International Pictures, which inaugurated its 'Poe adaptations' cycle in 1959-1960 (Worland, 2014). Contrary to the Mexican and Anglo-American film industries, churning out horror movies on an assembly-line basis ever since 1956, starting with Ladrón de cadáveres and The Curse of Frankenstein respectively (Tombs, 1997; Meikle, 2009), the Italian film industry didn't immediately join the trend: lacking a horror-hungry national audience and the possibilities for wide distribution on the European and North-American markets to be opened up in 1958-1959 by the worldwide box-office success of fantastic-tinged 'muscleman adventure' Le fatiche di Ercole (1958), I vampiri remained an 'isolated incident' for more than 2 years. A sustained production of horror-themed films in Italy began only in spring 1959, after the extraordinary performance of Hammer's Dracula on the international market stimulated demand for eerie pictures all over the world (Ursini and Silver, 1975; Murphy, 1979). In accordance with the scant Italian heritage of horror, the first Italian attempt to piggy-back Hammer's top-moneymaker was Tempi duri per i vampiri (1959), an Ultrascope-FerraniacolorTechnicolor parody of Fisher's hit backed by production and distribution company C.E.I.-Incom. Aware of the meagre boxoffice receipts gathered by prototype I vampiri on the domestic market, the makers of Tempi duri per $i$ vampiri cast recently-risen international horror star Christopher Lee as a bloodthirsty sexual predator from Mitteleuropa forced to flee to the bel paese, and added elements from the typically-Italian 'summer holiday' comedy subgenre (featuring bikini-clad beauties in gorgeous Italian sceneries and centred on the dichotomy between true love and sexual adventures). ${ }^{22}$ In a further attempt to move away from straightforward horror, Italian comic actor Renato Rascel got the role of protagonist, playing 'the fool' to 'straight man' Lee, and film direction was entrusted to Stefano 'Steno' Vanzina, who had been directing the most popular Italian comedians since 1949 and was one of the writers of 1942 seminal horror parody C'è un fantasma nel castello, broadcast to great success on Italian State Television in July 1954 and September 1955 (RAI, 1977). Then, between December 1959 and summer 1960, five vampire-themed horror movies 'of Italian nationality' were rushed into production thanks to the minimo garantito and/or state-credit mechanisms already described for I vampiri: Italo-French co-productions Il sangue e la rosa (1960) and Il mulino delle donne di pietra (1960), shot in colour at Cinecittà studios, and ' $100 \%$ Italian', black-andwhite pictures L'amante del vampiro (1960), La maschera del demonio (1960) and L'ultima preda del vampiro (1960)-plus Seddok, l'erede di Satana (1960), a Jekyll-and-Hyde adaptation trying to cash in on the succès de scandale of Italo-French medical thriller Les yeux sans visage (1960). Of all these films, constituting the 'first wave' of Italian horrors, only Il mulino delle donne di pietra and La maschera del demonio bear a macroscopic similarity to I vampiri: Il mulino delle donne di pietra features a female 'scientific vampire' kept alive by a mad doctor with blood transfusions, while La maschera del demonio, directed and photographed in Titanus studio by Freda's right-hand man and trusted cinematographer Bava, remakes I vampiri's 'accelerated aging' metamorphosis. Evidently, I vampiri was an experiment of little consequence within the frame of the Italian film industry trends and, as both the Italian film press of the early 1960s (Anonymous, 1960b, c; Fofi, 1963) and all horror scholars from Mora (1978) to Di Chiara (2016) duly note, it is more appropriate to consider Fisher's Dracula as the actual 'originary film' kickstarting Italian horror cinema.

As in Italian film criticism the expressions "film di vampiri" and "film di Dracula" quickly became a byword for horror cinema as a whole (Fink, 1960), the Hammer film was explicitly referenced/reworked not only in blatant parody Tempi duri per $i$ vampiri, but also in L'amante del vampiro (the 'bedroom seduction' scenes, the staking of a vampire-woman in her coffin and the gory 'final disintegration' of the villains in the sun), La maschera del demonio (the brawl between doctor Gorobec and vampire 
Javutich, and the cemetery raid featuring a Van-Helsing-like savant character) and L'ultima preda del vampiro (the fistfight showdown between the good guy and the vampire). The reasons behind this cinematic phenomenon are once again economic. After quite a few cuts required by the Italian Censorship Office to grant a VM16 rating (Ufficio di Revisione Cinematografica, 1958) and a ban by Vatican censors (Centro Cattolico Cinematografico, 1959), Dracula premiered in two well-known prima visione theatres in Rome 2 weeks before Christmas 1958 and, in spite of receiving very bad reviews (Anonymous, 1958-1959; Ghelli, 1959), ended up making around 600 million lira all over the country, most probably in the pricey, urban 'industrial circuit' of prima and seconda visione theatres, "ranking as the as the 28th highest-grossing film at the Italian box-office in the 1958-1959 season" (Pezzotta, 2014, p 35) and launching a 'vampire craze' that took the Italian media sphere by storm.

Firstly, in the wake of Dracula's release, newspapers started nicknaming any sex offender, burglar and juvenile delinquent a vampire (De' Rossignoli, 1961; Rossi-Osmida, 1978). As for periodicals, by 1960 virtually every magazine had published at least one article on vampirism, the specific subject dependant on the publication's area of expertise. For instance, showbiz monthly Sipario featured an article about youth gangs inspired by vampire movies and horror comics (Magli, 1959), while in medical magazine Progressi di terapia there was an article about physician Polidori, author of The Vampyre (Anonymous, 1960d). In this cultural climate, "radio drama Vampiro", featuring vampires being staked and dying screaming, was broadcast "twice over the course of just 2 months" on Italian State Radio (De' Rossignoli, 1961, p 347). On the much more popular (and closely-controlled by censorship) Italian State Television, monsters could only be played for laughs, so "comedians Ugo Tognazzi and Raimondo Vianello parodied Dracula during prime-time variety show Un due tre" (De' Rossignoli, 1961, p 348). This was followed by showbusiness veteran Rascel performing a 'vampire skit' during quiz show Il musichiere, as part of the promotional campaign for Tempi duri per $i$ vampiri (Della Casa and Giusti, 2014). The Italian music industry immediately jumped on the horror bandwagon too, thanks to composers Bruno Martino and Bruno Brighetti, who authored several tongue-in-cheek horror-themed songs (Magazù, 1960). In particular, Martino's Dracula cha-chacha became a hit during summer 1959, spawned a 1960 French version and featured prominently in the soundtrack of both Italian 'comedy of terrors' Tempi duri per $i$ vampiri and Rome-set Hollywood drama Two Weeks in Another Town (1962) (Curti, 2015). As for variety theatre, in 1959 a revue called Un juke-box per Dracula was put into production by Vianello's touring company and achieved great success (Anonymous, 1960a). Similar shows subsequently popped up in almost every theatre and music hall around the country, and even in night clubs of dubious fame (De' Rossignoli, 1961).

Secondly, as noted by Pezzotta (2014), in 1959 and 1960 Italian publishers flooded the market with horror literature and especially with vampire stories. In July 1959, Longanesi printed a new Italian translation of Bram Stoker's Dracula titled Dracula il vampiro, the same title chosen by distributor Universal for the Italian release of Fisher's film. ${ }^{23}$ Over the course of 1960, the most famous horror tales from Europe, America and Russia were published in three Italian-language anthologies, among which was established Milanese publisher Feltrinelli's I vampiri tra noi: 37 storie vampiriche ('Vampires among us: 37 vampire stories'), a 800-page volume boasting a preface by Roger Vadim in an attempt at cross-promoting Vadim's in-the-making Carmilla adaptation Il sangue e la rosa. Moreover, "the success obtained at the Italian boxoffice by Fisher's Dracula in early 1959 [...] convinced a few 'adventurous' small publishers based in Rome" and already active in the war, crime and sci-fi genres "to print horror-themed pulp novels and distribute them in newspaper stands all over Italy" (Cozzi and Bissoli, 2012, p 9-10). Such pulp novels-whose manuscripts were sold to publishers for around 50,000-60,000 lira each-were penned by Italian writers under English, German or French pseudonyms and tended to cannibalise the works of the renowned, foreign authors translated and published by Milanese colossuses Mondadori, Rizzoli, Longanesi and Bompiani. As a result, the KKK and I racconti di Dracula series were born, in June 1959 and December 1959 respectively, providing Italian readers with 'counterfeit-foreign' horror stories once or twice a month for 120-150 lira per issue (Cozzi and Bissoli, 2012; Cozzi and Lombardi, 2013), which corresponded to the average film-ticket price in 1959-1960 (Quaglietti, 1980).

In conclusion, scholars are definitely right in linking the birth of Italian horror cinema to the release of the 1958 Dracula and to the 'vampire craze' it triggered. Indeed, 1960s Italian horrors' parasitic, hybrid, transnational nature (meaning anything from blatant plagiarisms of Hammer's templates to more creative 'variations on the theme' mixing foreign models with distinctively national traits) is now a commonplace in film studies. Besides allowing Donati, Carpentieri and Lombardo to enact a small-scale financial speculation and suggesting some thematic and visual motives to be exploited by later Italian ventures into the macabre (e.g., the centrality of female characters and their Manichean division into angelic, chaste damsels-in-distress and hypersexed, evil temptresses) (Mora, 1978; Günsberg, 2005; Di Chiara, 2009), I vampiri merely confirmed a long-standing Italian bias against home-grown horror narratives. This prejudice, together with the 600 million lira gathered by Anglo-American joint venture Dracula at the Italian box-office, helps explaining why, in view of their domestic release, a substantial amount of Italian horrors from late 1959 onward tried to somewhat conceal, blur or mitigate their Italian origin through a wide variety of strategies such as: hiring foreign lead actors; setting the stories abroad; using foreign-sounding pseudonyms for Italian producers, screenwriters, directors, cast and crew; constantly referencing foreign literary sources and films; striking co-production and 'joint participation' agreements with other countries (which also, and perhaps most importantly, allowed for the extension of the 'Andreotti system' to the international film industry, giving Italian producers plenty of opportunities to 'creatively finance' movies by addressing the specific needs of foreign distributors) (Pirro, 1965; Mora, 1978; Pitassio, 2005; Curti, 2015; Baschiera, 2016). And, ultimately, the meagre returns obtained by the 1960 'first wave' of Italian horrors at the domestic box-office, combined with the extraordinary US success of Black Sunday (the re-dubbed, re-edited and re-scored version of La maschera del demonio prepared by American International Pictures for North-American distribution), laid the foundations for Italian horror to become the business of making "domestic films made for export" (Di Chiara, 2016), i.e., low-cost 'Italian-nationality' films reaping the benefits of the Christian-Democrat legislation while filling a demand on foreign markets.

Received: 21 June 2017 Accepted: 19 October 2017 Published online: 14 November 2017

\footnotetext{
Notes

1 E.g., Malombra (1917), Malombra (1942) and Il cappello da prete (1944).

2 E.g., Faust (1914), Il mostro di Frankenstein (1920), Rapsodia satanica (1917), L'altro io (1917), La giovinezza del diavolo (1922), Il cuore rivelatore (1935) and Il caso Valdemar (1936)
} 
3 E.g., Il diavolo zoppo (1909), Satana (1912), 'E scugnizze (1917) and Kalida'a la storia di una mummia (1917).

4 A list of pre-1957 Italian movies with a 'horror sensibility' should also include: Lo spettro (1907) and Il fantasma (1909), about vengeful ghosts leading murderers to confession; La strega di Siviglia (1908) and La ballata della strega (1910), about witchcraft; La madre e la morte (1911), about a woman attempting to rescue her child kidnapped by Death; La dama bianca (1916), an adaptation of Wilkie Collins' 1859 novel The Woman in White; I rettili umani (1915), about a mad scientist able to turn snakes into human beings; La bara di vetro (1915), La sposa dei secoli (1916), L'uomo dall'orecchio mozzato (1916) and L'uomo che dormì 130 anni (1922), about catalepsy or magical resurrections. As noted by Venturini (2014), many Italian silent movies include the words 'death', 'dead', 'corpse', 'blood', 'vampire', 'devil', 'ghost', 'nightmare', 'skeleton', 'fear' and 'terror' in the title, but they are not at all horror films. Rather, they are sensationalist melodramas or crime movies mainly inspired to Grand Guignol plays, which in 1908 had started to be performed to great popular success in Italy by actor Alfredo Sainati's itinerant company (Arduini, 2011).

5 E.g., Horace Walpole's 1764 The Castle of Otranto, Ann Radcliffe's 1797 The Italian, or the Confessional of the Black Penitents, James Malcolm Rymer and Thomas Peckett Prest's 1845-1847 Varney the Vampire; or, the Feast of Blood, Francis Marion Crawford's 1880 For the Blood is the Life...

6 To avoid wordy phrasings, throughout the article the noun 'Italy' and the adjective 'Italian' are used in relation to both the pre- and the post-unification period (the Kingdom of Italy was officially proclaimed in 1861, and prior to this date 'Italy' was just a geographical entity, a land below the Alps politically divided into different kingdoms, duchies, republics...).

7 Cf. Note sulla letteratura italiana nella seconda metà del secolo XIX. Boito-Tarchetti -Zanella, a 1904 essay by Croce stating that Italy is no country for the "Nordic cavalcade of spectres, dying virgins, angelic demons, [...] creaking skeletons, and sighs and cries and laughters of crazy people and the deliria of the feverish" (quoted in Curti, 2011, p 18). Judging from Praz (1930), Gramsci (1975a, p 945) and Gramsci (1975b, p 1933, p 2121), in the early 1930s the term 'Gothic' itself had little to no cultural currency in Italian literary studies, since The Castle of Otranto, The Italian and the like were commonly designed as 'black novels' [romanzo nero], 'frenetic novels' [romanzo frenetico/roman frénétique] or 'dark novels' [romanzo tenebroso].

8 Vampires are the protagonists of 'man-vs.-giant-bat' jungle adventures such as Emilio Salgari's 1912 Il vampiro della foresta, and of uncanny tales dealing either with beings that feed on human blood/energies (Francesco Ernesto Morando's 1885 Vampiro innocente; Giuseppe Tonsi's 1902 Il vampiro; Luigi Capuana's 1907 Un vampiro; Enrico Boni’s 1908 Vampiro; Vittorio Martella's 1917 Il vampiro; Giuseppe de Feo's 1921 Il vampiro) or life-draining portraits à la Poe (Daniele Oberto Marrama's $1907 \mathrm{Il}$ dottor Nero; Cifra's 1940 Il vampiro) (Cammarota, 1984; Tardiola, 1991; Foni, 2007). For the record, vampire lore is mentioned in passing in the following novels: Francesco Domenico Guerrazzi's 1854 Beatrice Cenci, Gabriele D'Annunzio's 1894 Il trionfo della morte and Edoardo Calandra's 1909 Juliette. Occasional references to bloodsucking creatures are also to be found in the literary efforts by Italian avantgardists such as the Scapigliati (Baudelaire-influenced Romantic/Decadent poets of the 1860s and 1870s) and the Futurists.

9 Cf. Freda (quoted in Cozzi, 2007, pp 324-325): "I vampiri originally opened with [a child murderer] sentenced to death and guillotined. But the basket containing his head is purloined by the doctor-character, the scientist. The doctor takes the head into his laboratory and, just like Frankenstein, sews it to the headless corpse of another man, bringing the creature back to life. [Later in the film, when confronted by the police, the resuscitated monster] loses his energy, falls to the ground, his head gets detached from the body and rolls away. [...] The producers forced me to remove these scenes: they were afraid that the film would be too strange, unconventional and impressive for Italian audiences. In short, they thought that the film would be less pleasant and therefore less commercial". Curiously, the producers' reworking of the story led Vatican censors to classify the film as belonging not to the horror genre but to both the "fantastico" and the "giallo" (murder mystery/crime) genre (Centro Cattolico Cinematografico, 1957, p 182). Some 1957 newspaper reviews also call the film a "giallo" (Anonymous, 1957d), "a mix of the giallo and the macabre-terrifying genre" (Anonymous, 1957e), a filmic equivalent of "giallo books" (Anonymous, 1957b). Indeed, I vampiri's plot-revolving around a journalist investigating the involvement of an aristocrat family in the murder of some girls, drained of blood and thrown into the Seine-might have been inspired by the real-life mystery known as 'the Wilma Montesi giallo', which was a sensation in Italy between 1953 and 1958 (21-year-old, working-class girl Montesi was found drowned on a beach near Rome in April 1953 and rich and powerful people were accused of her death by muckraking reporters, until all the suspects were acquitted in May 1957).

10 According to the personnel of the Italian Censorship Office (interviewed in November 2016), some files relating to foreign films imported during the Fascist ventennio might have been lost or destroyed in 1943-1945, so it is not certain that the above vampire classics were never imported. What is sure is that Nosferatu started being screened in Italian cinema circles in the late 1940s (Anonymous, 1948), while Vampyr was very well known to Italian critics ever since the late 1930s (Viazzi, 1940; Casiraghi, 1942; Doglio, 1948; Campassi, 1949; Carancini, 1949; Giani, 1951) and its screenplay-actually a 'movie transcript' desumed from a French film print-was published in Italian in the late 1940s (Buzzi \& Lattuada, 1948). Finally, it exists a 1936 promotional article launching the Italian edition of Mark of the Vampire under the title Il segno del vampiro: in the article, neither Bela Lugosi nor the words 'Dracula' and 'horror' are mentioned; rather, the selling points are the "dramatic qualities" of the picture, the action-packed murder-mystery plot and established star Lionel Barrymore playing a cunning detective (Anonymous, 1936)

11 Interestingly, Freda had already used the 'bet' metaphor eight years earlier, to explain why he started making adventure movies in 1940s Italy: "I wanted to prove that in Italy we could make adventure movies that were as good as the Hollywood ones" (Lourcelles \& Mizrahi, 1963, p 22).

12 According to Venturini (2014, p 104), the original 97-million budget had to be increased "due to the choice of shooting in anamorphic format (CinemaScope)". All production and distribution data relating to I vampiri come from the "Ministero del Turismo e dello Spettacolo. Direzione Generale Spettacolo. Lungometraggi (concessione certificato di nazionalità). 1946-1965' section of the Archivio Centrale dello Stato in Rome. I vampiri's file is labelled 'busta 167 CF 2548 '.

13 In the top-three for 1957 Italian movies we have Belle ma povere with 808,507,392 lira (Rondolino \& Levi, 1967, p 119), Lazzarella with 776,315,481 lira (Rondolino \& Levi, 1967, p 123) and Arrivederci Roma with 768,805,235 lira (Rondolino \& Levi, 1967, p 119).

14 The casting of French actor Antoine Balpêtré-a member of the renowned Comédie Française-in the small role of the Frankensteinian mad scientist proves that the producers thought of selling I vampiri on the French market from the very beginning.

15 It is unlikely that Longanesi named Matheson's book after Freda's 'half-fiasco' film. I is more probable that, sometime in 1956, the filmmakers got news that an American novel called I vampiri was to be published by Longanesi and decided to beat the editorial colossus on time. However, Freda never mentioned this fact, not even to claim that the title had been 'stolen' from him.

16 The import of American films in Italy had ceased on January 1st 1939, after a dispute between the Italian Fascist government and Hollywood majors over State monopoly (Quaglietti, 1991; Corsi, 2001).

17 Yet, as Quaglietti (1980) astutely remarks, by the end of the 1940s Hollywood majors' backlogs were almost exhausted and monopolising Italian screens through dumping was no longer possible anyway.

18 According to Argentieri (1974), Quaglietti (1980) and Corsi (2001), the 1949 regulations even survived the end of Christian Democracy's absolute majority in the Italian Parliament as law 1213 of November 4th 1965-informally named legge Corona' after socialist Achille Corona, the Minister of Tourism and Cultural Activities of the first centre-left government in the history of the Italian Republicshares with the 'leggina' and the 'legge Andreotti' an emphasis on state aids and automatic tax refunds (definitively fixed at $13 \%$ of the Italian box-office gross).

19 As noted by Lo Foco (1984) and Venturini (2001), producers could enact minimogarantito-like credit or deferred payment mechanisms also in relation to studio facilities, film labs and suppliers. Considering that I vampiri was almost entirely shot in Titanus studio in Rome and its soundtrack published by Titanus Edizioni, the financial involvement of Lombardo's company might have gone beyond cash investment via distribution agreements.

20 'Preventive censorship' was first introduced by Italy's Centrist government in 1919-1920 (Argentieri, 1974).

21 The Italian Censorship Office required two very brief shots featuring skulls and skeletons to be removed from the trailer only (Ufficio di Revisione Cinematografica, 1957).

22 For an in-depth thematic analysis of Tempi duri per $i$ vampiri see Guarneri (2016).

23 The first Italian edition of the novel Dracula - printed by Milanese publishing house Sonzogno in 1922 under the title Dracula. L'uomo della notte ('Dracula, the man of the night') as part of the 'mystery tales for the whole family' series Collezione per le famiglie. I racconti misteriosi-was an abridged version of Stoker's own abridged text of 1901. Certainly, the Italian translator didn't work on the English original but on the French edition of 1920, Dracula, l'homme de la nuit (same title, same cover art, same misspelling of the author's name as 'Brahm Stoker'). The Italian translation of the full, 1897 text of Dracula was first printed in September 1945 and again in 1952, by Milanese Fratelli Bocca Editori within its 'occult novels' series I romanzi dell'occultismo.

\section{References}

AAVV (1995) 98 Protagonisti si raccontano. In: Gili JA, Tassone A (eds) ParigiRoma: 50 anni di coproduzioni italo-francesi, 1945-1995. Il Castoro, Firenze, p 37-223

Agazzi R (1979) Il mito del vampiro in Europa. Lalli, Poggibonsi

Anonymous (1936) Il segno del vampiro. Cinema Illustrazione 16 (4)

Anonymous (1948) 'Nosferatu il vampiro' di F. W. Murnau: 28. Proiezione: domenica 2 maggio 1948. Circolo Romano del Cinema, Roma

Anonymous (1957a, 7 April) 'I vampiri'. Gazzetta del Popolo, unnumbered page. Anonymous (1957b, 15 April) 'I vampiri'. Il Giorno, unnumbered page. Anonymous (1957c, 16 April) 'I vampiri'. La Notte, unnumbered page. Anonymous (1957d, 30 May) 'I vampiri'. Il Tempo, unnumbered page. 
Anonymous (1957e, 30 May) 'I vampiri'. La Stampa, unnumbered page.

Anonymous (1958-1959) Prime visioni: Dracula. Cinematografia d'oggi 12-1, p 16

Anonymous (1960a) Dracula in gonnella e juke-b ox. Mascotte 1, p 32

Anonymous (1960b) L'orrore f atto in casa. Mascotte 8, p 38-41

Anonymous (1960c) La maschera del demonio. Mascotte 14, unnumbered pages.

Anonymous (1960d) Malati e medici del passato: i vampiri e il medico di Byron. Progress Ter 1:28-31

Arduini C (2011) Teatro sinistro: storia del Grand Guignol in Italia. Bulzoni, Roma

Argentieri M (1974) La censura nel cinema italiano. Editori Riuniti, Roma

Barattoni L (2013) Italian post-neorealist cinema. Edinburgh University Press, Edinburgh

Baschiera S (2016) The 1980s Italian horror cinema of imitation: the good, the ugly and the sequel. In: Baschiera S, Hunter R (eds) Italian horror cinema. Edinburgh University Press, Edinburgh, p 15-29

Baschiera S, Di Chiara F (2010) Once upon a time in Italy: Transnational features of genre production 1960s-1970s. Film Int 8(6):30-39

Bernardini A, Martinelli V (1993) Il cinema muto italiano: i film degli anni d'oro, 1913. Parte Seconda. Centro Sperimentale di Cinematografia, Roma

Bizzarri L (1957) Cinema senza industria (storia economica di dodici anni). Ponte 8-9:1370-1388

Burucoa C (1995) Gli accordi di coproduzione (1946-1995). In: Gili JA, Tassone A (eds) Parigi-Roma: 50 anni di coproduzioni italo-francesi, 1945-1995. Il Castoro, Firenze, p 18-23

Buzzi A, Lattuada B (1948) Vampyr: l'étrange aventure de David Gray. Poligono, Milano

Cammarota D (1984) I vampiri. Arte-Cinema-Folklore-Letteratura-Teatro-Storia \& altro. Fanucci, Roma

Campassi O (1949) Recenti aspetti del formalismo. Cinema 9(1):166-167

Carancini G (1949) Vampiri e 'vampirismo'. Cinema 12(4):363-364

Casiraghi U (1942) Vecchi film in museo: 'Vampyr'. Cinema 148(8):458-459

Centro Cattolico Cinematografico (1957) I vampiri. Segnalazioni cinematografiche 41, p 182

Centro Cattolico Cinematografico (1959) Dracula il vampiro. Segnalazioni cinematografiche $45, \mathrm{p} 103$

Clarens C (1968) Horror movies: an illustrated survey. Secker \& Warburg, London

Colombo M, Tentori A (1990) Lo schermo insanguinato: il cinema italiano del terrore 1957-1989. Solfanelli, Chieti

Corsi B (2001) Con qualche dollaro in meno. Storia economica del cinema italiano. Editori Riuniti, Roma

Cozzi L (1971) I maghi del terrore. L'orribile segreto del dottor Hampton. Intervista a Riccardo Freda. Horror 15(4):26-28

Cozzi L (2007) Ancora Riccardo Freda. In: Tentori A, Cozzi L (eds) Guida al cinema gotico italiano: horror made in Italy. Profondo Rosso, Roma, p 321-326

Cozzi L, Bissoli S (2012) La storia dei 'Racconti di Dracula'. Profondo Rosso, Roma

Cozzi L, Lombardi N (2013) La storia dei 'KKK I classici dell'orrore' - Incubi sul Tevere. Profondo Rosso, Roma

Curti R (2011) Fantasmi d'amore: il gotico italiano tra cinema letteratura e tv. Lindau, Torino

Curti R (2015) Italian Gothic horror films 1957-1969. McFarland, Jefferson

De' Rossignoli E (1961) Io credo nei vampiri. Ferciani, Milano

Della Casa S (1993) Mille comparse o un attore? Intervista a Riccardo Freda. In: Martini E, Della Casa S (eds) Riccardo Freda. Bergamo Film Meeting, Bergamo, p 53-61

Della Casa S, Giusti M (2014) Gotico italiano: il cinema orrorifico 1956-1979. Centro Sperimentale di Cinematografia, Roma

Di Chiara F (2009) I tre volti della paura. Il cinema horror italiano (1957-1965). UNIFE Press, Ferrara

Di Chiara F (2016) Domestic films made for export: modes of production of the 1960s Italian horror film. In: Baschiera S, Hunter R (eds) Italian horror cinema. Edinburgh University Press, Edinburgh, p 30-44

Doglio C (1948) Due linguaggi diversi: muto e sonoro. Cinema 3(11):70-71

Faldini F, Fofi G (1979) L'avventurosa storia del cinema italiano raccontata dai suoi protagonisti: 1935-1959. Feltrinelli, Milano

Faldini F, Fofi G (1981) L'avventurosa storia del cinema italiano raccontata dai suoi protagonisti: 1960-1969. Feltrinelli, Milano

Fink G (1960) Occhi senza volto. Cinema nuovo 147:457-458

Fofi G (1963) Terreur en Italie. Midi-Minuit Fantastique 7(11):81-83

Foni F (2007) Alla fiera dei mostri: racconti pulp, orrori e arcane fantasticherie nelle riviste italiane 1899-1932.. Tunué. Latina

Freda R, Fofi G, Pistagnesi P (1981) Riccardo Freda. Divoratori di celluloide: 50 anni di memorie cinematografiche e non. Emme, Milano

Ghelli N (1959) Dracula il vampiro. Rivista del cinematografo 1(1):31-32

Giani R (1951) Al vampiro piacquero i 'décors' di Silvagni. Cinema 77(12): 367-369

Gramsci A (1975a) Quaderni del carcere. Volume 2: Quaderni6-11. Einaudi, Torino
Gramsci A (1975b) Quaderni del carcere. Volume 3: Quaderni12-29. Einaudi, Torino Guarneri M (2016) Re-working the Count Dracula myth, re-negotiating class identity: the transnational vampire goes to late-1950s Italy. Art Commun Popculture 2:47-59

Günsberg M (2005) Italian cinema: gender and genre. Palgrave Macmillan, New York

Hunter R (2016) Preferisco l'Inferno: early Italian horror cinema. In: Baschiera S, Hunter R (eds) Italian horror cinema. Edinburgh University Press, Edinburgh, p 15-29

Lo Foco M (1984) Cinema: tutta la verità sul mondo del cinema. Akropolis, Roma Lourcelles J, Mizrahi S (1963) Entretien avec Riccardo Freda. Présence du cinéma 17:11-30

Magazù G (1960) Le canzoni del terrore. Mascotte 6:18

Magli A (1959) Psicologia e spettacolo: i vampiri minorenni. Sipario 11:17-18

Marinucci V (1957, 31 May) 'I vampiri'. Momento Sera, unnumbered page.

Martinelli V (1992) Il cinema muto Italiano: i film della Grande Guerra, 1915. Parte Seconda. Nuova ERI, Torino

Meikle D (2009) A history of horrors the rise and fall of the house of hammer Scarecrow Press, Plymouth

Mistrali F (1869) Il vampiro. Storia vera. Società tipografica dei compositori, Bologna

Mora T (1978) Storia del cinema dell'orrore (1957-1978), volume 2.2. Fanucci, Roma

Murphy MJ (1979) The celluloid vampires: a history and filmography (1897-1979). Pierian Press, Ann Arbor

Newman K (1986) Thirty years in another town: the history of Italian exploitation. Monthly Film Bull 624(1):20-24

Peirse A (2013) After Dracula: the 1930s horror film. I.B. Tauris, London

Pezzotta A (1997) Doppi di noi stessi. Segnocinema 85:25-31

Pezzotta A (2014) Il boom? È gotico (e anche un po' sadico). Bianco \& Nero 579:34-48

Pirro U (1965) Da «Caltiki» a «Un pugno di dollari». Ulisse 9:38-44

Pisoni R, Ferrarese M (2007) Il padre del mostro. Intervista a Riccardo Freda. In: Acerbo G, Pisoni R (eds) Kill Baby Kill!: il cinema di Mario Bava. Un mondo a parte, Roma, p 43-44

Pitassio F (2005) L'orribile segreto dell'horror italiano. In: Manzoli G, Pescatore G (eds) L'arte del risparmio: stile e tecnologia. Carocci, Roma, p 31-41

Praz M (1930) La carne, la morte e il diavolo nella letteratura romantica. Società Editrice La Cultura, Milano; Roma

Quaglietti L (1980) Storia economico-politica del cinema italiano 1945-1980. Editori Riuniti, Roma

Quaglietti L (1991) Ecco i nostri: l'invasione del cinema americano in Italia. ERI Torino

RAI (1977) Tv titoli: opere liriche, operette e commedie musicali, drammi e commedie, originali televisivi, riduzione di opere letterarie, films, telefilms trasmessi in televisione dal 1954 al 1975 . ERI, Torino

Rondolino G, Levi O (1967) Catalogo Bolaffi del cinema italiano. Tutti i film del dopoguerra (1945-1965). Bolaffi, Torino

Rossi-Osmida G (1978) Uomini o vampiri. Curcio, Milano

Rotellar M (1952) Terrore sugli schermi. Cinema 99-100(12):296-306

Tardiola G (1991) Il vampiro nella letteratura italiana. De Rubeis, Anzio

Tibaldi Chiesa M (1936) Gli enigmi del vampiro. Mondadori, Milano

Tombs P (1997) Mondo Macabro. Titan Books, London

Treveri Gennari D (2011) Post-War Italian cinema: American intervention, Vatican interests. Taylor \& Francis, Hoboken

Troiano F (1989) L'horror. In: Salizzato C (ed) Prima della rivoluzione. Schermi italiani 1960-1969. Marsilio, Venezia, p 95-101

Ursini J, Silver A (1975) The vampire film. Tantivy Press, London

Valli B (1999) Il film ideale: i cattolici, il cinema e le comunicazioni sociali. Angeli, Milano

Venturini S (2001) Galatea S.p.A. (1952-1965): storia di una casa di produzione cinematografica. Associazione italiana per le ricerche di storia del cinema Roma

Venturini S (2014) Horror italiano. Donzelli, Roma

Viazzi G (1940) Vampyr. Bianco \& Nero 10:92-95

Ufficio di Revisione Cinematografica (1957) Visto di censura 23894. Ministero per i Beni e le Attività Culturali-Direzione Generale per il Cinema, Roma

Ufficio di Revisione Cinematografica (1958) Visto di censura 28085. Ministero per Beni e le Attività Culturali-Direzione Generale per il Cinema, Roma

Wagstaff C (1998) Italian genre films in the world market. In: Nowell-Smith G, Ricci S (eds) Hollywood and Europe: economics, culture, national identity, 1945-1995. BFI, London, p 74-85

Worland R (2014) The Gothic revival (1957-1974). In: Benshoff HM (ed) A companion to the horror film. Wiley, Malden, p 273-291

\section{Data availability}

Data sharing is not applicable to this paper as no datasets were generated or analysed. 


\section{Acknowledgements}

The author thanks Russ Hunter, Paolo Noto, Peter Hutchings, Johnny Walker,

Francesco Di Chiara, Italia Taglia and the personnel of the Archivio Centrale dello Stato in Rome.

\section{Additional information}

Competing interests: The author declares no competing financial interests.

Reprints and permission information is available online at http://www.nature.com/ reprints

Publisher's note: Springer Nature remains neutral with regard to jurisdictional claims in published maps and institutional affiliations. (c) (i) Open Access This article is licensed under a Creative Commons Attribution 4.0 International License, which permits use, sharing, adaptation, distribution and reproduction in any medium or format, as long as you give appropriate credit to the original author(s) and the source, provide a link to the Creative Commons license, and indicate if changes were made. The images or other third party material in this article are included in the article's Creative Commons license, unless indicated otherwise in a credit line to the material. If material is not included in the article's Creative Commons license and your intended use is not permitted by statutory regulation or exceeds the permitted use, you will need to obtain permission directly from the copyright holder. To view a copy of this license, visit http://creativecommons.org/ licenses/by/4.0/.

(C) The Author(s) 2017 